\title{
The giant pleomorphic adenoma of the palate
}

\author{
Olbrzymi gruczolak wielopostaciowy podniebienia \\ ${ }^{1}$ Department of Oral Surgery and Periodontology, Poznan University of Medical Sciences, Poland \\ ${ }^{2}$ Department of Otolaryngology, District Hospital in Skarżysko-Kamienna, Poland
}

DOI: http://dx.doi.org/10.20883/df.2018.33

\begin{abstract}
Pleomorphic adenoma (PA) is the most common benign tumour of the major or minor salivary glands. Among the minor salivary glands, the hard palate is the most common site, accounting for approximately $50 \%-60 \%$. A giant PA can destroy bony compartment and can require extensive reconstruction with either an extraoral or an intraoral flap dissection. The aim of the paper was to present the clinical manifestations and results of treating palatal PA and to mark its most typical clinical features and surgical approaches. Surgical treatment of palatal PA depends on the tumour size and involvement of the adjacent soft tissues and bone. Only the most severe tumour presentations with major bone destruction require periosteum removal. All postoperative palatal defects should be closed by intraoral or extraoral flaps. Free skin graft from the tight can be a good surgical choice to reconstruct palatal postoperative defects.
\end{abstract}

Keywords: pleomorphic adenoma, mixed tumour, minor salivary glands.

\section{STRESZCZENIE}

Gruczolak wielopostaciowy jest najczęstszym guzem łagodnym dużych i małych gruczołów ślinowych. Wśród małych gruczołów ślinowych, podniebienie twarde jest najczęstszym miejscem występowania, stanowiąc w przybliżeniu 50-60\%. Olbrzymi gruczolak wielopostaciowy może niszczyć kość i może wymagać rekonstrukcji z wytworzeniem zewnątrzustnego lub wewnątrzustnego płata. Celem pracy było przedstawienie postaci klinicznej i wyników leczenia gruczolaka wielopostaciowego podniebienia i wskazanie jego najbardziej typowych cech klinicznych i dostępów chirurgicznych. Leczenie chirurgiczne zależy od rozmiaru guza i włączeniu w proces chorobowy kości i okolicznych tkanek miękkich. Tylko najcięższe postacie guza z dużą destrukcją kości wymagają usunięcia okostnej. Wszystkie ubytki pooperacyjne podniebienia muszą być zamknięte przez zewnątrzustne lub wewnątrzustne płaty. Wolny przeszczep skóry z biodra może być dobrym wyborem chirurgicznym dla zamknięcia pooperacyjnych ubytków podniebienia.

Słowa kluczowe: gruczolak wielopostaciowy, guz mieszany, małe gruczoły ślinowe.

\section{Introduction}

Pleomorphic adenoma (PA) or benign mixed tumour is the most common benign tumour of the major or minor salivary glands. It accounts for $54-65 \%$ of all salivary gland neoplasias and $80 \%$ of benign salivary gland tumours. PA arises most commonly in the parotid gland; about $80 \%$ are reported in the parotid, $10 \%$ in the submandibular gland and $10 \%$ in the minor salivary glands of the oral cavity, nasal cavity and paranasal sinuses and the upper respiratory and alimentary tracts. Among the minor salivary glands, the hard palate is the most common site, accounting for approximately $50-60 \%$, followed by the upper lip
(15-20\%) and buccal mucosa (8-10\%). It is usually slow-growing, painless, and firm on palpation. Possible complications for treatment include the risk of recurrence and malignant transformation. PA exhibits great histological diversity, such as differentiation into oncocytic, sebaceous, mucinous, squamous, chondroid, osseous or adipose cells. Extensive squamous metaplasia can be mistaken for malignancy, including mucoepidermoid carcinoma and squamous cell carcinoma. Its complex histological structure is the cause of diagnostic difficulties, especially regarding locations within the minor salivary glands [1-4]. 
A giant PA can destroy bony compartment and can require extensive reconstruction with either an extraoral or an intraoral flap dissection.

\section{Aim}

The aim of the paper was to present the clinical manifestations and results of treating palatal PA and to mark its most typical clinical features and surgical approaches.

\section{Case report}

A 64-year-old woman was admitted to the Department of Neurology of the District Hospital in Skarzysko-Kamienna. The reason for admission was numbness of the right upper and lower limb. Computed tomography of the head revealed small ischemic changes in the brain. Intraoral examina- tion in the Department of Laryngology of the District Hospital in Skarzysko-Kamienna detected an oval-shaped, giant, circumscribed tumour on the right palatal side, adherent to the underlying structures, covered with slightly erythematous palatal mucosa. The size of the lesion was $5 \mathrm{~cm}$ in diameter. The tumour did not interfere with the patient's daily activities. Clinical diagnosis of PA was suspected and confirmed with incisional biopsy. After stabilization of the patient's neurological condition, the tumour was completely removed under general anaesthesia with nasal intubation, leaving the periosteum. A free full thickness split from the thigh was placed on the periosteum. A compression dressing was placed on the graft. After 5 days, the dressing was removed and the graft was healing. A histopathological examination confirmed

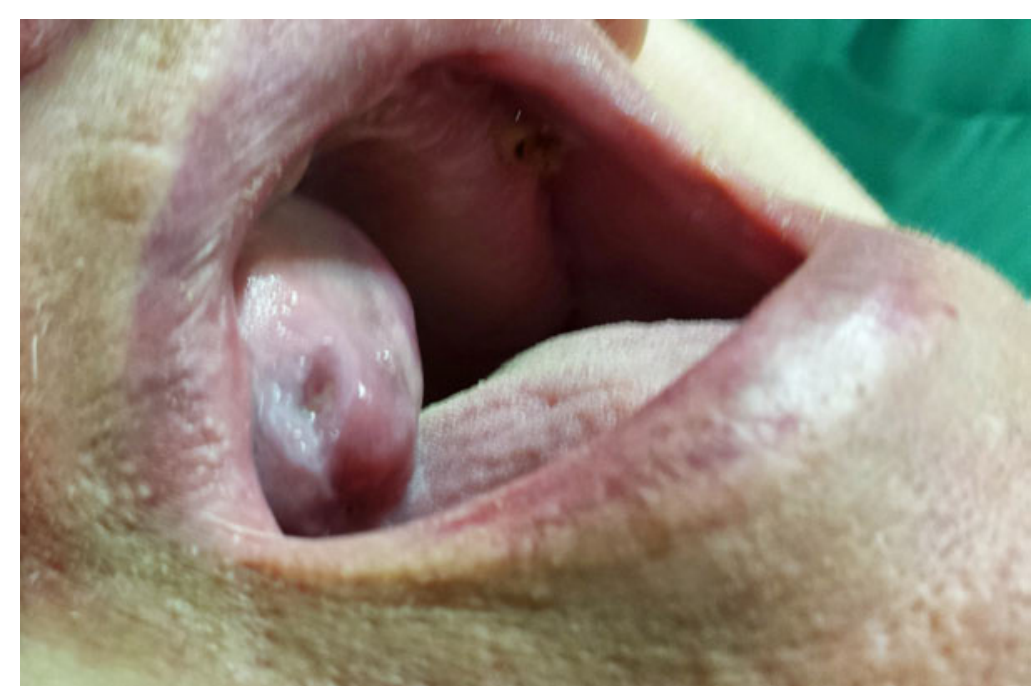

Figure 1. The giant pleomorphic adenoma of the palate

Rycina 1. Olbrzymi gruczolak wielopostaciowy podniebienia

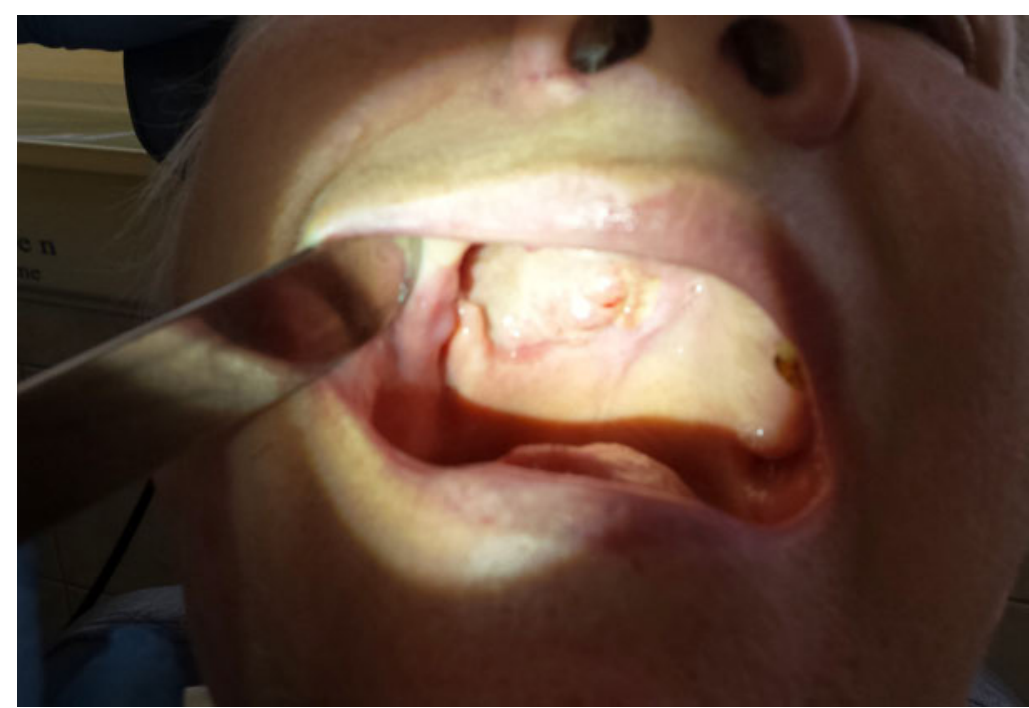

Figure 2. Pleomorphic adenoma after surgical procedure

Rycina 2. Gruczolak wielopostaciowy po zabiegu operacyjnym 
PA, completely removed with margins without neoplasias. The 24-month follow-up recall revealed good healing of the palate without recurrence of the tumour.

\section{Discussion}

The clinical presentation of a PA of the hard palate is typically a firm or rubbery submucosal mass without ulceration or surrounding inflammation. Pain and tenderness are unusual. Tumour growth is slow. Smooth or multilobulated swelling over the hard palate is the most common clinical feature. Bleeding, ulceration and itching are rare symptoms. In our case, smooth painless swelling overlaying normal mucosa was the predominant symptom, too. Even so, the giant tumour did not interfere with the patient's daily activities.

Computed tomography is very useful in diagnosis and planning surgical treatment and can reveal an intact hard palate with minor erosion or no erosion or full thickness erosion of the hard palate. The involvement of the infratemporal fossa or floor of orbit or erosion of the maxillary sinus wall can mimic a malignancy and require more extensive surgical approaches. An intact hard palate or its minor erosion are the most favourable prognosis. Differential diagnosis of PA includes odontogenic and non-odontogenic cysts, soft tissue tumours such as fibroma, lipoma, neurilemmoma, neurofibroma and rhabdomyosarcoma, palatal abscess and salivary gland tumours, particularly mucoepidermoid carcinoma and adenoid cystic carcinoma [5].

Typical features of PA are a focally very thin capsule, the absence of encapsulation, pseudopodia projecting into the surrounding tissue or satellite nodules outside the capsule. These features have their clinical implications and increase the risk of recurrences. The results of other studies indicate that the majority (68-100\%) of PAs of intraoral minor salivary glands are either partially encapsulated or nonencapsulated [3]. The high ratio of nonencapsulated structures requires more extensive surgical methods to minimize the risk of recurrences. Extensive surgical treatment is also required because of potentially primary or secondary malignant manifestation of PA. Carcinoma ex pleomorphic adenoma (CXPA) is an unusual epithelial malignancy that develops from a primary or recurrent PA. On histopathological examination, the CXPA comprises a wide morphological spectrum with a variable proportion between the benign and malignant components, with the latter often predominating and overlapping the $P A$, which may cause misdiagnosis [5]. The pathogenesis of CXPA rema- ins unclear, but the accumulation of genetic alterations on long-standing tumors seems to be a crucial event in carcinomatous transformation of PA.

The treatment of choice for PA in the minor salivary glands is wide local excision with the removal of periosteum or bone if they are involved. Simple enucleation of this tumour leads to a high local recurrence rate and should be avoided [6]. Longevity and recurrence are risk factors for malignant transformation. The propensity for malignant transformation is documented to be $1.9-23.3 \%$ [7]. The primary goal of excision should be complete removal of the mass without risking recurrence. Surgical treatment depends on possible hard palate erosion and the involvement of the adjacent bony compartments. In cases of an intact hard palate or an intact hard palate with minor erosions, excisions of mass with underlying periosteum and curettage of any hard palate bone involved is the most recommended method. In more severe full thickness erosion of hard palate, reconstruction by palatal flap is required. In cases of the most severe bone destruction total maxillectomy and reconstruction by obturator are needed [5]. According to Sharma et al., tumours of the hard palate should be excised down to the periosteum, including the overlying mucosa with $1 \mathrm{~cm}$ clinical margins at the periphery [8]. Excision of palatal bone is not required as periosteum is an effective anatomical barrier. If the tumour extends to the soft palate, the excision should include the fascia over the muscles of the soft palate. In our case, the periosteum was left, too. In our opinion, the periosteum is an effective anatomical barrier for tumour growth and recurrence and prompts the proper postoperative healing. Extensive palatal surgery can lead to loss of palatal mucosa integrity. Various surgical techniques have been suggested for the closure of palatal defects, which include secondary healing, palatal flaps, tongue flaps, and turnover flaps of adjacent mucoperiosteum. The simplest method for the closure of the palatal defect is an adjacent mucosal flap. This treatment produces excellent results. The excised region can also be left to heal by secondary intention. In this case, the tumour itself serves as a tissue expander, to advance adequate mucosal coverage, and achieve primary healing [7]. In our opinion, the main limitation of this method is tumour size. Giant PAs are a contraindication for adjacent mucosal flap application. All surgical methods should ensure the complete tumour resection with a low risk of recurrence and the reliable reconstruction of the palate [8]. One of the recommended surgical methods is a graft from the buc- 
cal fat pad. The free fat tissue graft harvested from the buccal fat pad can be used to reconstruct the soft-tissue defects of the palate. It is a simple procedure with minor complications; manipulation and handling the graft are easy. According to Kablan, there was complete epithelialization of the graft at the recipient sites after 3 months [10]. The possible complications include distant dehiscence and necrosis, limitation in mouth opening, mild obliteration of the vestibule, limitation of passing it through dentate areas that can compromise the blood supply, and the limitation of its applications at large defects and in lesions at the anterior regions in the oral cavity. In our case, the skin graft from the tight was used to reconstruct the hard palate. In our opinion, this method should be taken into consideration, especially in giant PA. It is a reliable reconstruction with minimal postoperative complications. This method of reconstruction does not limit mouth opening and does not decrease the prosthetic area for future dentures. Skin flap from the tight provided rich blood supply and favourable condition for uncomplicated healing. The surgical approach to the palate is possible by Le Fort I osteotomy. The Le Fort I osteotomy approach allows direct visualization of the tumour and ensures a wide excision, increasing safety and minimizing the possibility of recurrence [11]. There is also a possible reconstruction of postoperative palatal defects by removable partial dentures or obturators [12]. In our opinion, this method of reconstruction decreases the patient's quality of life and should not be recommended. It can be applied only in the most difficult surgical approaches.

\section{Conclusions}

The hard palate is the most common intraoral site for PA. Surgical treatment of palatal PA depends on the tumour size and involvement of the adjacent soft tissues and bone. Only the most severe tumour presentations with major bone destruction require periosteum removal. All postoperative palatal defects should be closed by intraoral or extraoral flaps. Free skin graft from the tight can be a good surgical choice to reconstruct palatal postoperative defects.

\section{Acknowledgements}

\section{Conflict of interest statement}

The authors declare that there is no conflict of interest in the authorship or publication of contribution.

\section{Funding sources}

There are no sources of funding to declare.

\section{References}

[1] Pereira T, Shetty S. Pleomorphic adenoma of palate with predominant chondroid tissue: A rarity. J Cancer Res Ther. 2018;14(2):476-477.

[2] Tandon A, Jaiswal R, Siddiqui S, Bordoloi B. Keratinizing pleomorphic adenoma: An unusual case report. J Oral Maxillofac Pathol. 2018;22(Suppl. 1):69-72.

[3] Wu YC, Wang YP, Cheng SJ, Chen HM, Sun A, Chang JY. Clinicopathological study of 74 palatal pleomorphic adenomas. J Formos Med Assoc. 2016;115(1):25-30.

[4] Ramesh M, Krishnan R, Paul G. Intraoral minor salivary gland tumours: a retrospective study from a dental and maxillofacial surgery centre in salem, Tamil Nadu. J Maxillofac Oral Surg. 2014;13(2):104-108.

[5] Patigaroo SA, Patigaroo FA, Ashraf J, Mehfooz N, Shakeel M, Khan NA, Kirmani MH. Pleomorphic adenoma of hard palate: an experience. J Maxillofac Oral Surg. 2014;13(1):36-41.

[6] Sedassari BT, da Silva Lascane NA, Tobouti PL, Pigatti FM, Franco MI, de Sousa SC. Carcinoma ex pleomorphic adenoma of the palate composed of invasive micropapillary salivary duct carcinoma and adenoid cystic carcinoma components: an unusual case with immunohistochemical approach. Medicine (Baltimore). 2014;93(27):e146.

[7] Sahoo NK, Rangan MN, Gadad RD. Pleomorphic adenoma palate: Major tumor in a minor gland. Ann Maxillofac Surg. 2013;3(2):195-197.

[8] Sharma Y, Maria A, Chhabria A. Pleomorphic adenoma of the palate. Natl J Maxillofac Surg. 2011;2(2):169171.

[9] Rahnama M, Orzędała-Koszel U, Czupkałło L, Lobacz M. Pleomorphic adenoma of the palate: a case report and review of the literature. Contemp Oncol (Pozn). 2013;17(1):103-106.

[10] Kablan F. The use of buccal fat pad free graft in closure of soft-tissue defects and dehiscence in the hard palate. Ann Maxillofac Surg. 2016;6(2):241-245.

[11] Sotong JP, Zavattero E, Garzino-Demo P, Bianchi FA, Ramieri G. The Le Fort I osteotomy as surgical approach of an extensive pleomorphic adenoma of the palate. J Craniofac Surg. 2015;26(3):e262-4.

[12] Debnath SC, Saikia AK, Debnath A. Pleomorphic adenoma of the palate. J Maxillofac Oral Surg. 2010;9(4):420-423.

Acceptance for editing: 2018-10-16 Acceptance for publication: 2018-12-05

Correspondence Author:

Katarzyna Błochowiak

Department of Oral Surgery and Periodontology, Poznan University of Medical Sciences, Poland 70 Bukowska Street, 61-812 Poznan, Poland email: kasia@naszdentysta.com.pl 